\title{
PEMANFAATAN SISTEM INFORMASI AKUNTANSI DALAM PERHITUNGAN PENDAPATAN ATAS HUTANG ANGGOTA KOPERASI
}

\author{
Sri Murni[1]; Latifah ${ }^{[2]}$; Fransisca Endah[3]; Dede Apriana[4], Raja Sabaruddin[5] \\ Sistem Informasi[1] \\ Sistem Informasi Akuntansi[2][3][4][5] \\ Universitas Bina Sarana Informatika[2][3][4][5] \\ www.bsi.ac.id[2][3][4][5] \\ sri.six@bsi.ac.id[1]; Latifah.lat@bsi.ac.id[2]; fransiscaendah57@gmail.com ${ }^{[3]}$; \\ Dedeapriana113@gmail.com[4]; Raja.rjd@bsi.ac.id[5]
}

\begin{abstract}
Information systems help companies to present financial reports in the form of accurate and reliable information. Accounting information systems provide great benefits in increasing the effectiveness and excellence of a company, especially in decision making. Recording and processing of transactions that occur in cooperatives in general already use Microsoft Excel, but the application is still less effective and does not meet the needs of users, as happened in the Consumption Cooperative of PT. Parna Agromas. Members of the cooperative are employees of the company PT. Parna Agromas. Employees are required to become members and spend both cash and in debt. Spending for members must not exceed salaries and at the end of the month a close book report will be used to deduct salary. In addition, the cooperative manager is responsible for the preparation of financial statements at the end of each period and of course requires an accounting information system. The application development method used is a waterfall, where the stages of this method consist of analysis, design, coding, implementation and supporting stages. The research resulted in an accounting information system in the form of an application that can be utilized in calculating the income of the members' debts and preparing the end of period report.
\end{abstract}

Key Words : Accounting Application, Income Calculation, Cooperative Member Debt

Intisari-Sistem informasi membantu perusahaan untuk menyajikan laporan keuangan ke dalam bentuk informasi yang akurat dan terpercaya. Sistem informasi akuntansi memberikan manfaat besar dalam meningkatkan efektifikas dan keunggulan sebuah perusahaan terutama dalam pengambilan keputusan. Pencatatan dan pengolahan transaksi yang terjadi pada koperasi secara umum sudah memanfaatkan microsoft excel, namun penerapannya masih kurang efektif dan belum memenuhi kebutuhan pengguna, seperti yang terjadi pada Koperasi Konsumsi PT. Parna Agromas. Anggota koperasi merupakan karyawan perusahaan PT. Parna Agromas. Karyawan diwajibkan menjadi anggota dan melakukan pembelanjaan baik secara tunai maupun hutang. Pembelanjaan anggota tidak boleh melebihi gaji dan pada akhir bulan dibuat laporan tutup buku yang akan digunakan dalam pemotongan gaji. Selain itu pengelola koperasi bertanggung jawab dalam penyusunan laporan keuangan setiap akhir periode dan tentunya memerlukan sistem informasi akuntansi. Metode pengembangan aplikasi yang digunakan adalah waterfall, dimana tahapan metode ini terdiri dari analisis, desain, pengkodean, implementasi dan tahap pendukung. Penelitian menghasilkan sistem informasi akuntansi dalam bentuk aplikasi yang dapat dimanfaatkan dalam perhitungan pendapatan atas hutang anggota dan penyusunan laporan akhir periode.

Kata Kunci: Aplikasi Akuntansi, Perhitungan Pendapatan, Hutang Anggota Koperasi

\section{PENDAHULUAN}

Teknologi informasi merupakan suatu kebutuhan yang dapat membantu kinerja organisasi, perusahaan maupun individu sehingga banyak membawa perubahan bagi organisasi maupun proses bisnis. Sistem informasi akuntansi akan membantu perusahaan untuk menyajikan laporan keuangan ke dalam bentuk informasi yang akurat dan terpercaya, sehingga banyak pihak yang memanfaatkan sistem informasi akuntansi 
untuk meningkatkan keunggulan bagi perusahaan. Sistem informasi adalah komponen dan elemen dari suatu organisasi yang menyediakan informasi bagi pengguna dengan pengolahan peristiwa keuangan(Alannita \& Suaryana, 2014).

Pada penelitian terkait dengan studi kasus pada koperasi Simpan Pinjam Manunggal Karya bahwa sangat diperlukan alat pengelolaan data secara cepat dan akurat terutama dalam pengelolaan Sisa Hasil Usaha (SHU). Alat tersebut berupa aplikasi peminjaman dan perhitungan yang menghasilkan laporan Sisa Hasil Usaha (SHU) dan data dapat disimpan pada database(Ningsih, Isnaini, Handayani, \& Neneng, 2017).

Dalam penelitian lain pada koperasi serba usaha Tangerang, aplikasi yang dibangun berupa aplikasi simpan pinjam yang dapat mengakomodasi pencarian data, pencatatan transaksi dan menghasilkan informasi berupa daftar anggota, simpanan, pinjaman, angsuran dan informasi perdagangan sembako(Karmawan, 2014).

Penelitian terdahulu lainnya yaitu pada koperasi pegawai negeri di kantor gubernur Kalimantan Barat. Koperasi berupa simpan pinjam dan menjual berbagai barang. Aplikasi yang dibangun dapat memanajemen penjualan dengan memberikan verifikasi customer yang akan melakukan transaksi secara kredit, menentukan batas kredit, menginformasikan barang kadaluarsa, stok barang dan menghasilkan laporan diantaranya laporan transaksi, retur, angsuran dan laba (AnnisaSari dkk, 2016).

Beberapa penelitian terdahulu yang dipaparkan di atas membuktikan bahwa perlunya sebuah sistem informasi pada koperasi untuk menggantikan sistem pengolahan data secara konvensional. Hal ini bertujuan untuk menghasilkan informasi yang cepat, tepat dan berkualitas pada objek penelitian. Aplikasi komputer yang tercipta saat ini memiliki jenis yang bermacam-macam seperti aplikasi yang mempermudah dalam melakukan perhitungan sampai dengan suatu aplikasi yang menyediakan sarana untuk melakukan pengolahan data. Aplikasi-aplikasi ini memiliki tujuan yang sama yaitu mempermudah unit kerja (Sihombing, Nugraha, \& Andani, 2016).

Koperasi Konsumsi PT. Parna Agromas merupakan salah satu koperasi konsumsi yang menjual barang-barang kebutuhan sehari-hari (sembako) kepada anggota koperasi yang dimana anggota merupakan karyawan PT. Parna Agromas. Sebuah perusahaan yang bergerak di bidang perkebunan kelapa sawit. Koperasi hanya menjual barang-barang kepada anggota baik secara tunai maupun hutang. Jumlah hutang anggota kepada koperasi tidak boleh melebihi gaji karyawan dan pembayaran hutang dilakukan dengan memotong gaji karyawan tanpa adanya bunga atas hutang perbelanjaan.

Pencatatatan transaksi koperasi seperti pencatatan hutang anggota, pendaftaran anggota, persediaan barang, bukti pengadaan barang dan bukti barang rusak masih berupa berkas sebagai media pencatatan dan akan direkapitulasi menggunakan Microsoft Excel untuk menghasilkan laporan tutup buku, laporan pengadaan barang, laporan barang rusak dan laporan persediaan barang. Maka dari itu diperlukan sebuah sistem informasi akuntansi dalam bentuk aplikasi untuk meningkatkan efektivitas dalam mengelola data-data menjadi bentuk laporan khususnya laporan perhitungan perhitungan atas pendapatan hutang anggota.

\section{BAHAN DAN METODE}

Peneliti menggunakan metode penelitian deskriptif yaitu metode penelitian yang menggambarkan objek atau subjek yang diteliti sesuai dengan yang terjadi, bertujuan untuk menggambarkan secara sistematis, fakta dan karakteristik objek yang diteliti secara tepat (Hariwijaya, 2017).

Untuk mendukung metode penelitian ini, digunakan teknik pengumpulan data dan metode pengembangan software.

1. Teknik Pengumpulan Data

a. Observasi

Melakukan observasi atau pengamatan langsung terhadap objek penelitian dalam mencatat dan menyusun pendapatan atas hutang anggota.

b. Wawancara

Wawancara dilakukan dengan mengajukan pertanyaan-pertanyaan yang berkaitan dengan penelitian kepada bapak Harianto selaku bendahara, bapak Johan selaku admin, dan bapak Alpian Sabinus selaku pengurus dan ketua koperasi konsumsi karyawan di PT. Parna Agromas.

c. Studi Pustaka

Menggunakan kajian-kajian untuk memberi landasan pada penelitian yang bersumber dari artikel, jurnal dan buku yang ada di perpustakaan dan perpustakaan online.

2. Metode Pengembangan Software 
Metode pengembangan software, peneliti menggunakan model air terjun atau waterfall. Model air terjun menyediakan pendekatan alur hidup perangkat lunak secara sekuensial atau terurut dimulai dari analisis, desain pengkodean, pengujian dan tahap pendukung (support).

a. Analisia kebutuhan software

Proses pengumpulan kebutuhan dilakukan secara intensif untuk menspesifikasikan kebutuhan perangkat lunak agar dapat dipahami perangkat lunak terkait seperti apa yang dibutuhkan oleh user dengan mengamati dan menganalisa dokumendokumen terkait.

b. Desain

Mendesain kebutuhan sistem yang terkait dengan rancangan database, software architecture dan user interface menggunakan Unified Modelling Language (UML), Entity Relationship Diagram (ERD) dan Logical Relational Structure (LRS).

c. Code Generation

Implementasi desain ke dalam code generation menggunakan pemrograman PHP, Java Script, CSS dan SQL.

d. Testing

Pengujian fokus pada perangkat lunak secara dari segi lojik dan fungsional dan memastikan semua bagian telah di uji dengan menggunakan black box testing sebagai metode pengujian software dengan cara menguji interface user.

\section{HASIL DAN PEMBAHASAN}

Penelitian menghasilkan sebuah aplikasi koperasi yang dapat diterapkan pada objek penelitian khususnya koperasi konsumsi PT. Parna Agromas. Aplikasi dapat digunakan oleh petugas-petugas terkait dimana aplikasi dapat digunakan untuk mencatat dan mengolah data transaksi koperasi sehingga menghasilkan informasi diantaranya informasi anggota, supplier, persediaan barang, barang rusak, daftar belanja, penjualan, arus kas, laba/rugi dan tutup buku. Fokus penelitian pada perhitungan pendapatan atas hutang anggota sehingga dapat digunakan oleh ketua dan pihak terkait dalam mengukur operasional koperasi dan pengambilan keputusan. Penelitian yang dilakukan menghasilkan kebaharuan dari penelitian sebelumnya berupa notifikasi barang yang kadaluarsa dan menghasilkan laporan keuangan berupa arus kas, pendapatan dan tutup buku.

Tahapan penelitian dalam pemgembangan aplikasi dimulai dari tinjauan kasus, desain, pembuatan aplikasi, pengujian dan implementasi.

1. Tinjauan Kasus

Proses pelaporan keuangan pada koperasi konsumsi memiliki peranan penting dalam penilaian hasil kerja pengelolaan koperasi yang berdampak pada kelangsungan hidup koperasi itu sendiri. Secara umum prosedur sistem berjalan untuk proses pendaftaran anggota, pengadaan barang, transaksi pengeluaran atau penjualan, dan laporan akhir pada koperasi konsumsi memiliki prosedur yang sama. Berikut pemaparan prosedur sistem berjalan pada objek penelitian yaitu Koperasi Konsumsi PT. Parna Agromas yang digambarkan dalam bentuk activity diagram.

a. Pengadaan Barang Koperasi

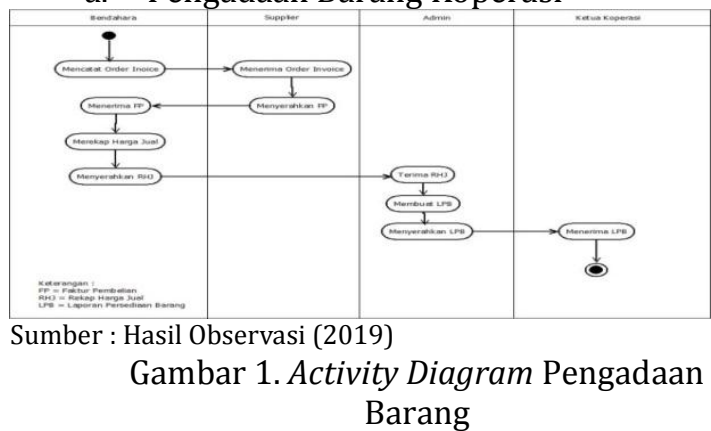

b. Transaksi Penjualan Barang

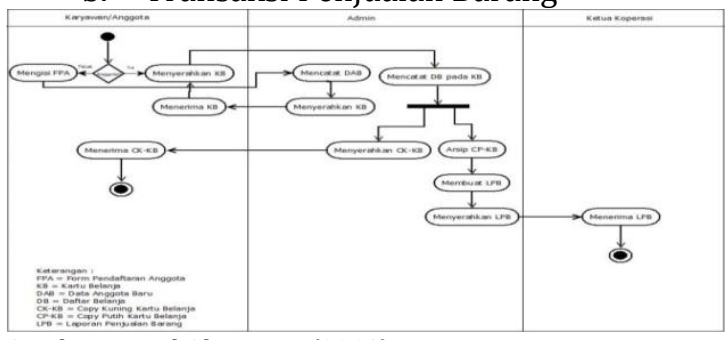

Sumber : Hasil Observasi (2019)

Gambar 2. Activity Diagram Transaksi Penjualan

c. Pendataan Barang Rusak

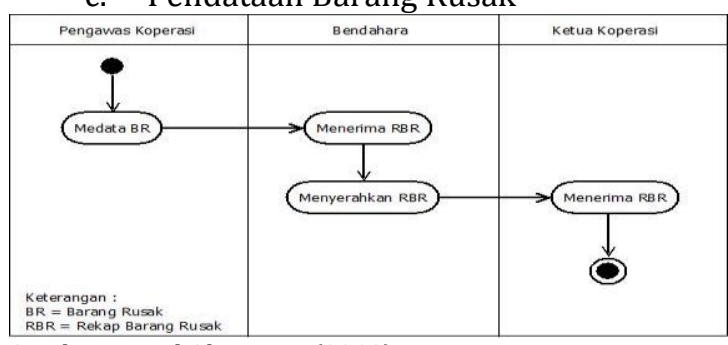

Sumber : Hasil Observasi (2019)

Gambar 3. Activity Diagram Pendataan Barang Rusak

2. Analisa Kebutuhan Software

Sistem informasi akuntansi perhitungan Pendapatan Atas Hutang anggota koperasi dapat dimanfaatkan oleh admin, bendahara dan ketua operasi dalam mengelola koperasi. Analisis kebutuhan software menerangkan apa saja yang dapat dilakukan oleh aplikasi 
sehingga dapat memenuhi kebutuhan pengguna.

a. Kebutuhan Pengguna

1) Admin
a) Login
b) Mengelola Data Anggota
c) Mengelola Transaksi Penjualan
d) Mengakses Laporan Persediaan Barang
e) Logout

2) Bendahara
a) Login
b) Mengelola Data Barang
c) Mengelola Data Supplier
d) Mengelola Pengadaan Barang
e) Mengelola Barang rusak
f) Mengelola Harga Barang
g) Mengakses Laporan Persediaan Barang
h) Mengakses Laporan Pengadaan
i) Mengakses Laporan Penjualan Barang
j) Logout

3) Ketua Koperasi
a) Login
b) Mengelola Data user
c) Mengakses Laporan
d) Logout

b. Kebutuhan Sistem

1) Pengguna diharuskan melakukan login terlebih dahulu dengan cara mengisi username dan password, apabila login berhasil maka setiap pengguna dapat mengakses aplikasi sesuai akses yang ditentukan

2) Pencarian Data anggota dan barang menggunakan kata kunci nama dan ID.

3) Daftar transaksi barang dapat dilihat melalui nama anggota yang telah melakukan transaksi tunai ataupun hutang berdasarkan tanggal transaksi anggota tersebut.

4) Bendahara dapat menentukan harga jual.

5) Laporan tutup buku, arus kas, dan laba rugi dapat dicari berdasarkan bulan dan tahun yang dapat diakses oleh ketua koperasi.

6) Pengguna harus melakukan logout ketika sudah selesai menggunakan aplikasi.

c. Use Case Diagram

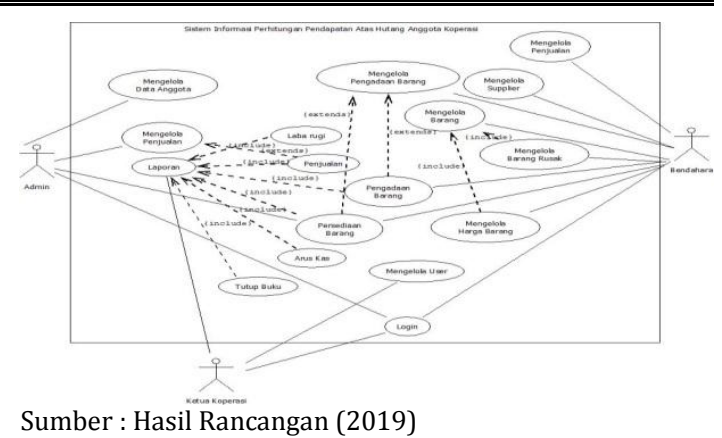

Gambar 4. Use Case Diagram Aplikasi

3. Basis Data

a. Entity Relationship Diagram

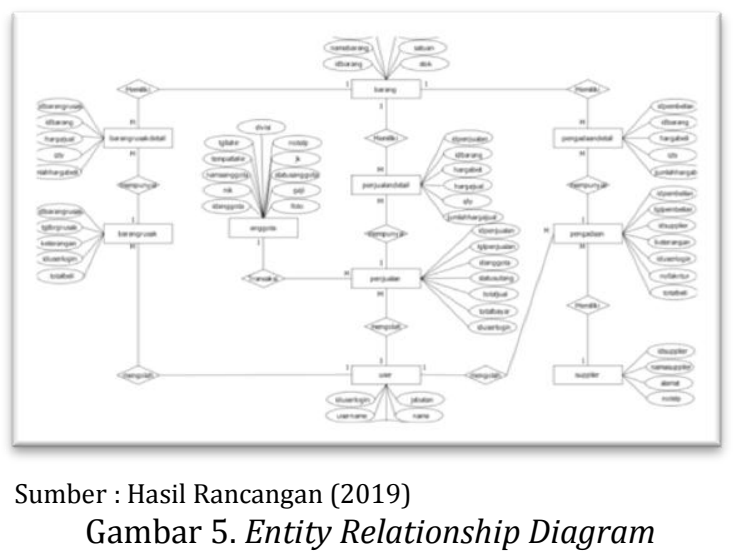

b. Logical Record Structure

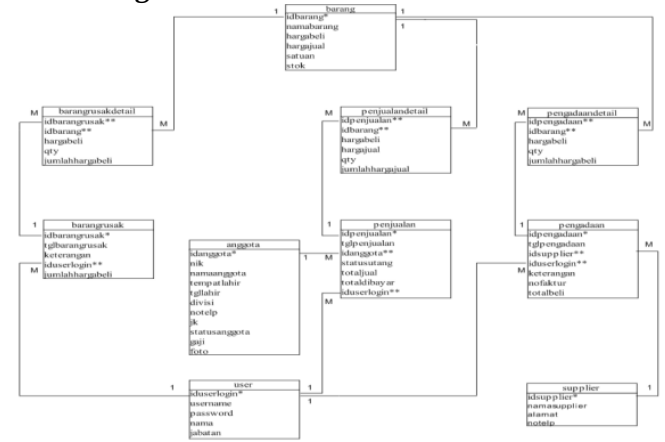

Sumber : Hasil Rancangan (2019)

Gambar 6. Logical Record Structure

c. Spesifikasi File

1) File Anggota

Tabel 1. Spesifikasi File Anggota

\begin{tabular}{|c|c|c|c|c|}
\hline No & Nama Field & Tipe Data & Panjang & Keterangan \\
\hline 1 & idanggota & int & 11 & Primary Key \\
\hline 2 & nik & varchar & 16 & \\
\hline 3 & namaanggota & varchar & 100 & \\
\hline 4 & tempatlahir & varchar & 100 & \\
\hline 5 & tgllahir & date & (null) & \\
\hline 6 & divisi & char & 1 & \\
\hline 7 & notelp & char & 16 & \\
\hline 8 & jk & char & 1 & \\
\hline 9 & statusanggota & char & 1 & \\
\hline 10 & gaji & decimal & 18 & \\
\hline 11 & foto & varchar & 255 & \\
& \multicolumn{2}{|l}{} & \\
& & & & \\
\end{tabular}


JURNAL KHATULISTIWA INFORMATIKA, VOL. VII, NO. 2 BULAN DESEMBER 2019

p-ISSN: 2339-1928 I e-ISSN: 2579-633X

Tabel 2. Spesifikasi File Barang

\begin{tabular}{|c|c|c|c|c|}
\hline No & Nama Field & Tipe Data & Panjang & Keterangan \\
\hline 1 & idbarang & int & 11 & Primary Key \\
\hline 2 & namabarang & varchar & 50 & \\
\hline 3 & hargabeli & decimal & 18 & \\
\hline 4 & hargajual & decimal & 18 & \\
\hline 5 & satuan & varchar & 15 & \\
\hline 6 & stok & int & 11 & \\
\hline
\end{tabular}

3) File Barang Rusak

Tabel 3. Spesifikasi File Barang Rusak

\begin{tabular}{|c|c|c|c|c|}
\hline No & Nama Field & Tipe Data & Panjang & Keterangan \\
\hline 1 & idbarangrusak & int & 11 & Primary Key \\
\hline 2 & tglbarangrusak & date & $($ null $)$ & \\
\hline 3 & keterangan & varchar & 255 & \\
\hline 4 & iduserlogin & int & 3 & Foreign Key \\
\hline 5 & totalbeli & decimal & 18 & \\
\hline
\end{tabular}

4) File Detail Barang Rusak

Tabel 4. Spesifikasi File Detail Barang Rusak

\begin{tabular}{|c|c|c|c|c|}
\hline No & Nama Field & Tipe Data & Panjang & Keterangan \\
\hline 1 & idbarangrusak & Int & 11 & Foreign Key \\
\hline 2 & idbarang & Int & 11 & Foreign Key \\
\hline 3 & hargabeli & decimal & 18 & \\
\hline 4 & gty & Int & 11 & \\
\hline 5 & jumlahhargabeli & decimal & 18 & \\
\hline
\end{tabular}

5) File Penjualan

Tabel 5. Spesifikasi File Penjualan

\begin{tabular}{|c|c|c|c|c|}
\hline No & Nama Field & Tipe Data & Panjang & Keterangan \\
\hline 1 & idpenjualan & Int & 11 & Primary Key \\
\hline 2 & tglpenjualan & Date & $($ null $)$ & \\
\hline 3 & idanggota & Int & 11 & Foreign Key \\
\hline 4 & statusutang & Char & 1 & \\
\hline 5 & totaljual & Decimal & 10 & \\
\hline 6 & totaldibayar & Decimal & 10 & \\
\hline 7 & iduserlogin & Int & 3 & Foreign Key \\
\hline
\end{tabular}

6) File Detail Penjualan

Tabel 6. Spesifikasi File Detail Penjualan

\begin{tabular}{|c|c|c|c|c|}
\hline No & Nama Field & Tipe Data & Panjang & Keterangan \\
\hline 1 & Idpenjualan & Int & 11 & Foreign Key \\
\hline 2 & Idbarang & Int & 11 & Foreign Key \\
\hline 3 & Hargabeli & Decimal & 18 & \\
\hline 4 & Hargajual & Decimal & 18 & \\
\hline 5 & Qty & Int & 11 & \\
\hline 6 & jumlahhargajual & Decimal & 18 & \\
\hline
\end{tabular}

7) File Pengadaan

Tabel 7. Spesifikasi File Pengadaan

\begin{tabular}{|c|c|c|c|c|}
\hline No & Nama Field & Tipe Data & Panjang & Keterangan \\
\hline 1 & idpengadaan & int & 10 & Primary Key \\
\hline 2 & tglpengadaan & date & $($ null) & \\
\hline 3 & idsupplier & int & 10 & Foreign Key \\
\hline 4 & keterangan & varchar & 255 & \\
\hline 5 & iduserlogin & int & 3 & Foreign Key \\
\hline 6 & nofaktur & char & 15 & \\
\hline 7 & totalbeli & decimal & 18 & \\
\hline
\end{tabular}

8) File Detail Pengadaan

Tabel 8. Spesifikasi File Detail Pengadaan

\begin{tabular}{|c|c|c|c|c|}
\hline No & Nama Field & Tipe Data & Panjang & Keterangan \\
\hline 1 & Idpengadaan & Int & 10 & Foreign Key \\
\hline 2 & Idbarang & Int & 11 & Foreign Key \\
\hline 3 & Hargabeli & Decimal & 18 & \\
\hline 4 & Qty & Int & 11 & \\
\hline 5 & jumlahhargabeli & Decimal & 18 & \\
\hline
\end{tabular}

9) File Supplier

Tabel 9. Spesifikasi File Supplier

\begin{tabular}{|c|c|c|c|c|}
\hline No & Nama Field & Tipe Data & Panjang & Keterangan \\
\hline 1 & Idsupplier & Int & 10 & Primary Key \\
\hline 2 & namasupplier & Varchar & 50 & \\
\hline 3 & alamat & Varchar & 255 & \\
\hline 4 & notelp & Char & 16 & \\
\hline
\end{tabular}

10) File User

Tabel 10. Spesifikasi File User

\begin{tabular}{|c|c|c|c|c|}
\hline No & Nama Field & Tipe Data & Panjang & Keterangan \\
\hline 1 & iduserlogin & Int & 3 & Primary Key \\
\hline 2 & username & Varchar & 50 & \\
\hline 3 & password & Varchar & 50 & \\
\hline 4 & nama & Varchar & 100 & \\
\hline 5 & jabatan & Char & 1 & \\
\hline
\end{tabular}

\section{User Interface}

User interface merupakan kegiatan membuat tampilan aplikasi sesuai kebutuhan pengguna yang telah dirancang sebelumnya.

a. Halaman Login

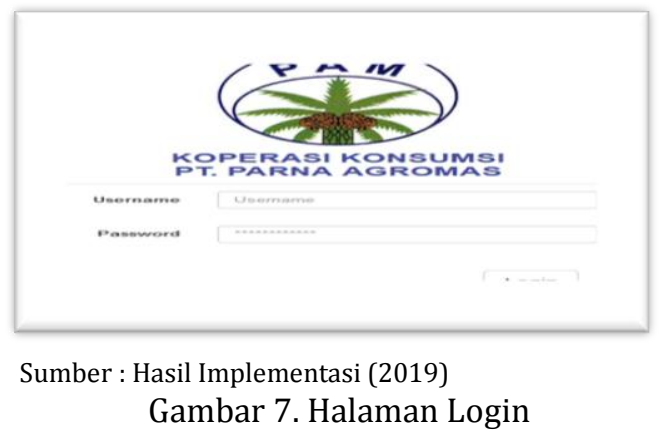

b. Dashboard Admin

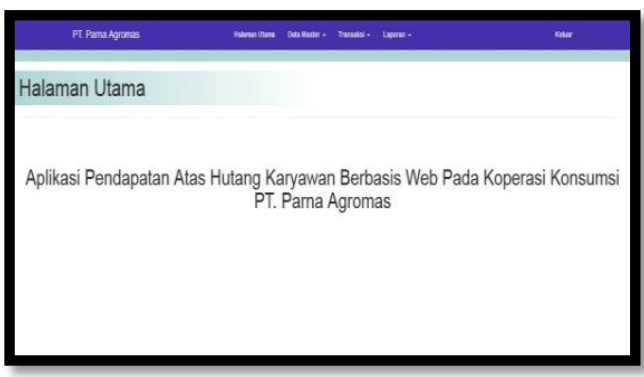

Sumber : Hasil Implementasi (2019) Gambar 8. Dashboard Admin

c. Halaman Data Anggota

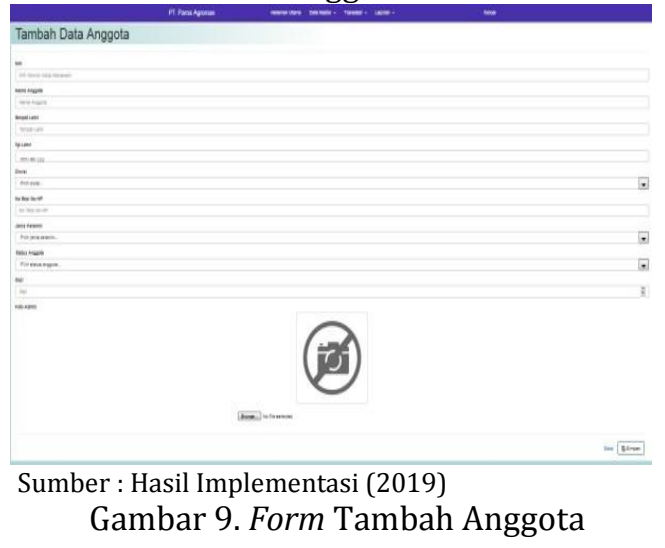




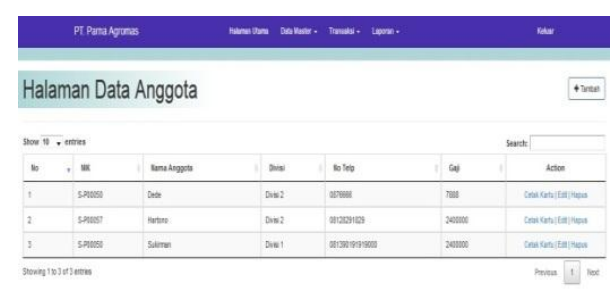

Sumber : Hasil Implementasi (2019)

Gambar 10. Daftar Anggota

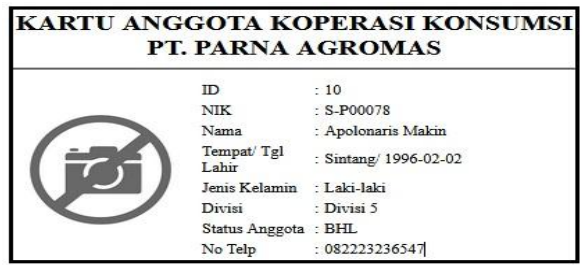

Sumber : Hasil Implementasi (2019)

Gambar 11. Kartu Anggota

d. Halaman Transaksi

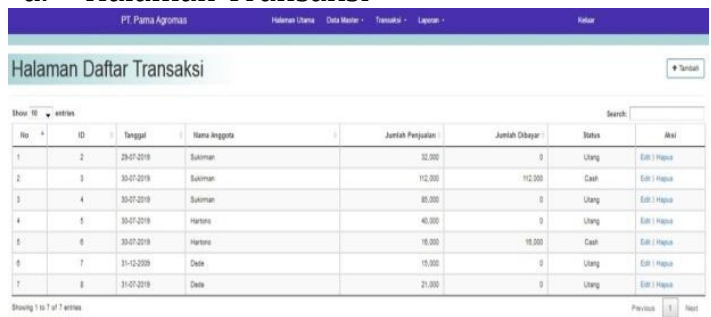

Sumber : Hasil Implementasi (2019)

Gambar 12. Daftar Transaksi

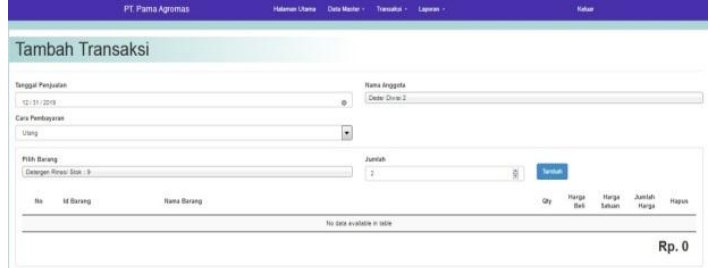

Sumber : Hasil Implementasi (2019)

Gambar 13. Tambah Transaksi

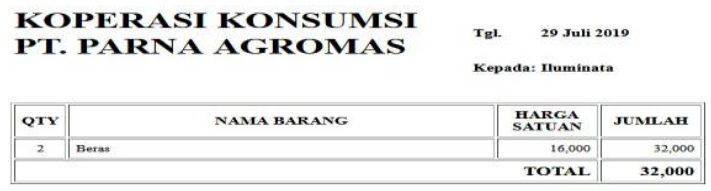

Sumber : Hasil Implementasi (2019)

Gambar 14. Bukti Transaksi

e. Halaman Persediaan Barang

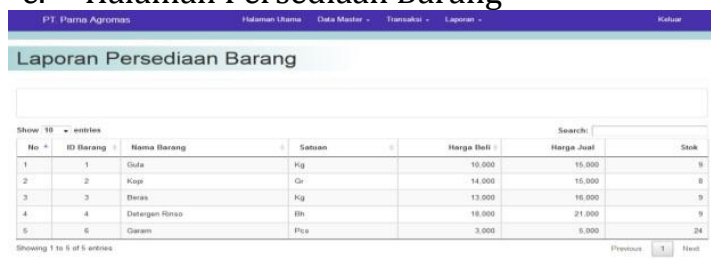

Sumber : Hasil Implementasi (2019)

Gambar 15. Daftar Persedian Barang

\section{f. Dashboard Bendahara}

Halaman Utame

Aplikasi Pendapatan Atas Hutang Karyawan Berbasis Web Pada Koperasi Konsumsi

Sumber : Hasil Implementasi (2019)

Gambar 16. Dashboard Bendahara

g. Halaman Data Barang

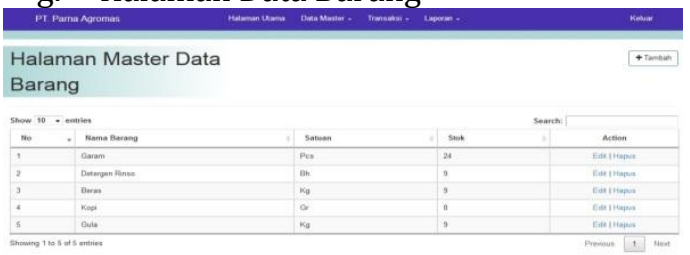

Sumber : Hasil Implementasi (2019)

Gambar 17. Daftar Barang

Tambah Master Data Barang

$=$

Sumber : Hasil Implementasi (2019)

Gambar 18. Tambah Barang

h. Halaman Data Supplier

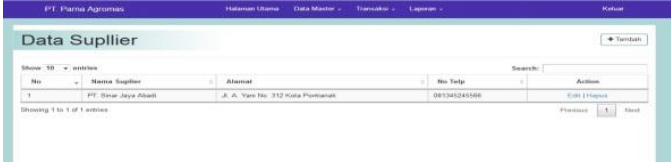

Sumber : Hasil Implementasi (2019)

Gambar 19. Daftar Supplier

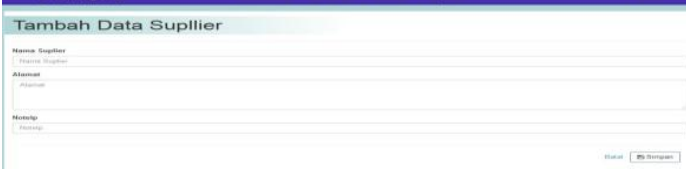

Sumber : Hasil Implementasi (2019)

Gambar 20. Tambah Data Supplier

i. Halaman Pengadaan Barang

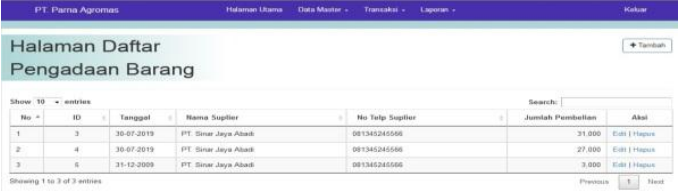

Sumber : Hasil Implementasi (2019)

Gambar 21. Daftar Pengadaan Barang

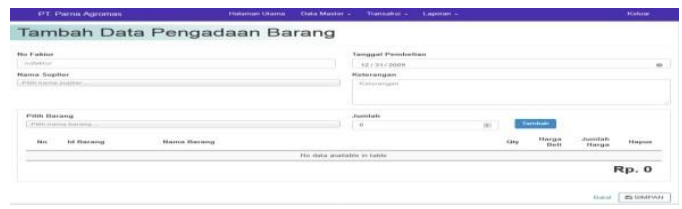

Sumber : Hasil Implementasi (2019)

Gambar 22. Tambah Data Pengadaan Barang 
j. Halaman Barang Rusak atau Kadaluarsa

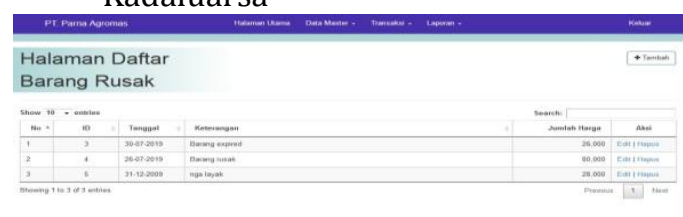

Sumber : Hasil Implementasi (2019)

Gambar 23. Daftar Barang Rusak

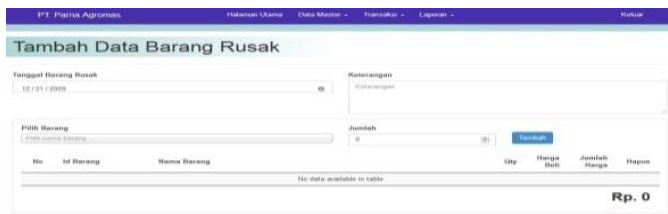

Sumber : Hasil Implementasi (2019)

Gambar 24. Tambah Data Barang Rusak

k. Halaman Harga Jual

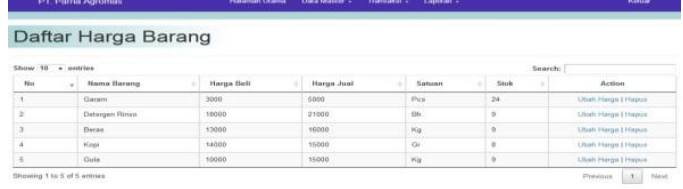

Sumber : Hasil Implementasi (2019)

Gambar 25. Daftar Harga Barang

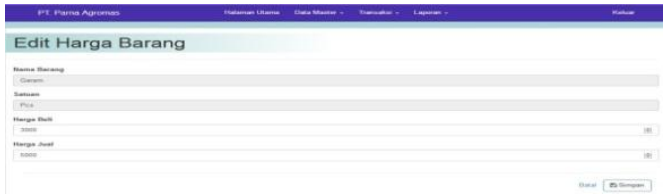

Sumber : Hasil Implementasi (2019)

Gambar 26. Form Edit Harga Barang

\section{Halaman Laporan}

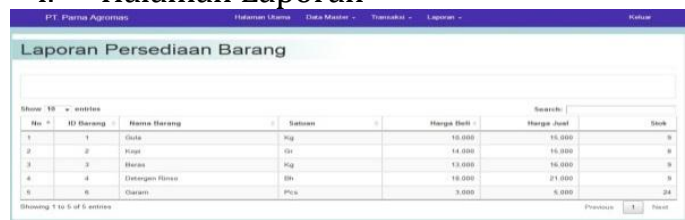

Sumber : Hasil Implementasi (2019)

Gambar 27. Data Persediaan Barang

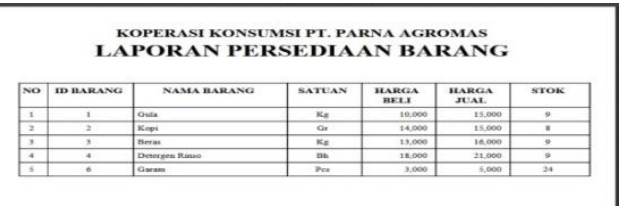

Sumber : Hasil Implementasi (2019)

Gambar 28. Laporan Persediaan Barang

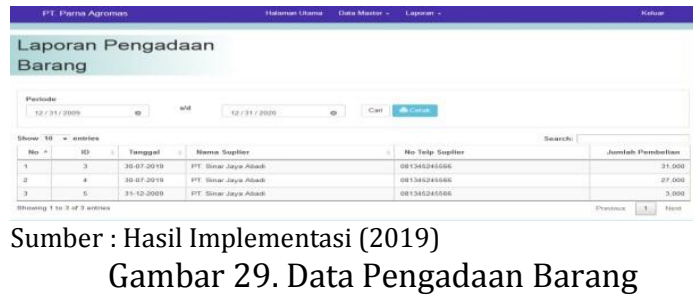

Gambar 29. Data Pengadaan Barang

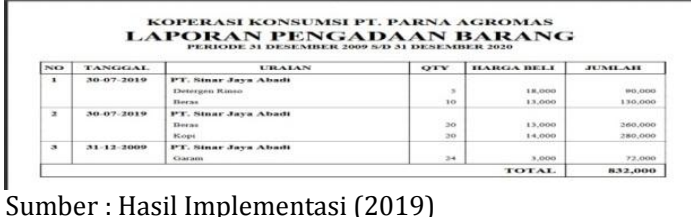

Sumber : Hasil Implementasi (2019)

Gambar 30. Laporan Pengadaan Barang

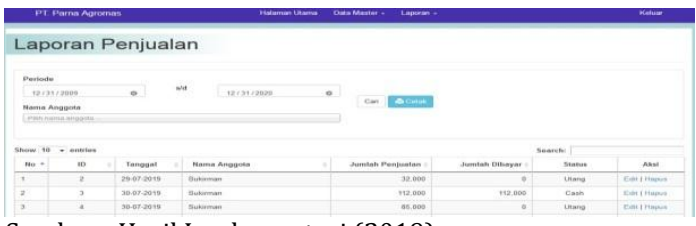

Sumber : Hasil Implementasi (2019)

Gambar 31. Data Penjualan
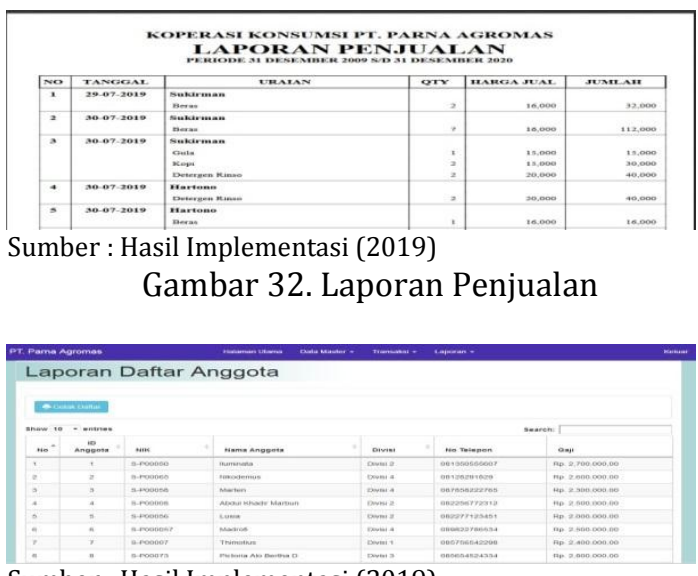

Sumber : Hasil Implementasi (2019)

Gambar 33. Daftar Anggota

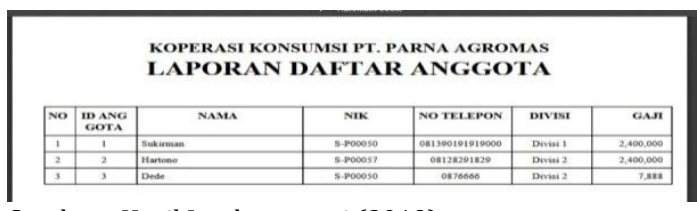

Sumber : Hasil Implementasi (2019)

Gambar 34. Laporan Data Anggota

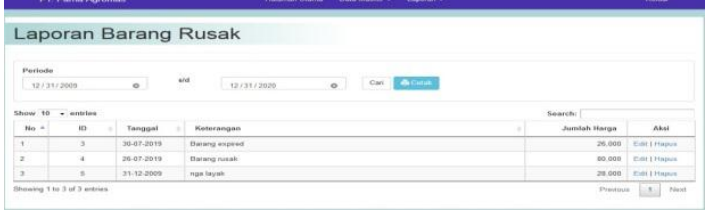

Sumber : Hasil Implementasi (2019)

Gambar 35. Daftar Barang Rusak

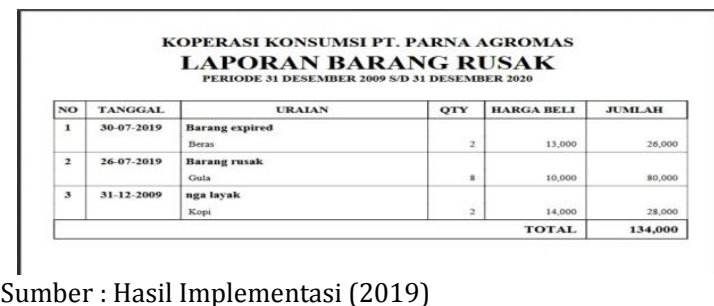

Sumber : Hasil Implementasi (2019)

Gambar 36. Laporan Barang Rusak 


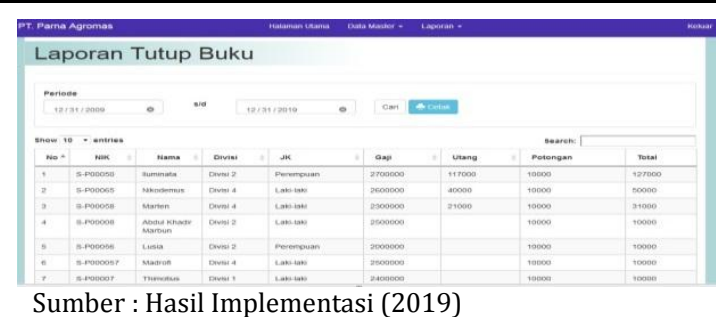

Gambar 37. Halaman Tutup Buku

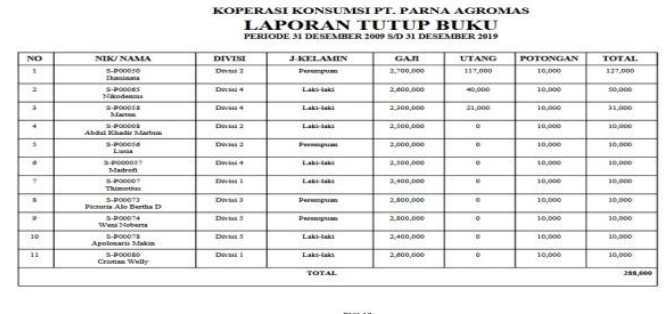

Sumber : Hasil Implementasi (2019)

Gambar 38. Laporan Tutup Buku

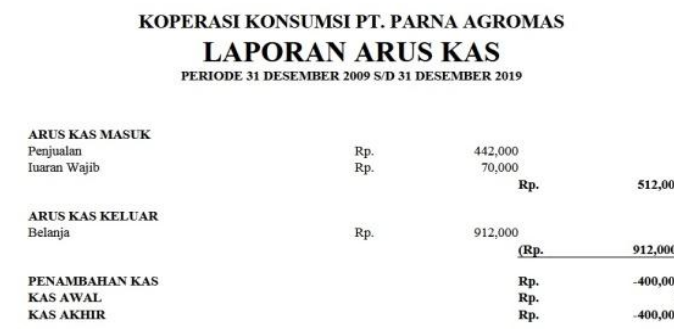

Sumber : Hasil Implementasi (2019)

Gambar 39. Laporan Arus Kas

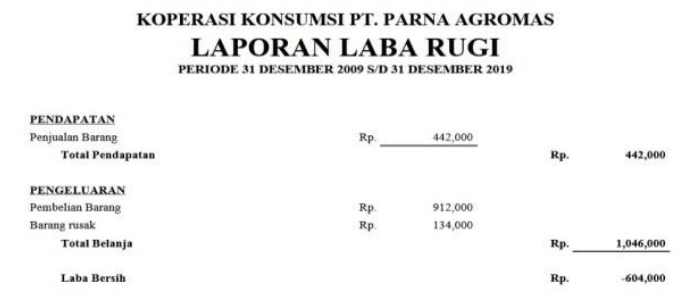

Sumber : Hasil Implementasi (2019)

Gambar 40. Laporan Laba Rugi

\section{KESIMPULAN}

Hasil penelitian menunjukkan bahwa pembangunan aplikasi perhitungan pendapatan atas hutang anggota dapat diimplementasikan pada PT. Parna Agromas untuk menggantikan pencatatan pada microsoft excel seperti pencatatan hutang anggota, pengadaan barang, persediaan barang dan rekapitulasi barang rusak.

Aplikasi dapat digunakan oleh 3 aktor atau pengguna diantaranya admin, bendahara dan ketua koperasi. Akses atau pemanfaataan dari aplikasi tersebut untuk setiap levelnya adalah Admin mengelola proses pendaftaran anggota, mengelola transaksi hutang maupun tunai dan dapat mengakses laporan persediaan barang. Bendahara mengelola secara penuh data barang yang dimulai dari pengadaan barang, penentuan harga jual, pendataan barang rusak, mengakses laporan pengadaan dan persediaan barang. Sedangkan Ketua koperasi mengelola hak akses pengguna aplikasi dan secara penuh dapat melihat seluruh laporan.

\section{REFERENS}

Alannita, N., \& Suaryana, I. (2014). Pengaruh Kecanggihan Teknologi Informasi, Partisipasi Manajemen, Dan Kemampuan Teknik Pemakai Sistem Informasi Akuntansi Pada Kinerja Individu. E-Jurnal Akuntansi, 6(1), 33-45.

Hariwijaya, M. (2017). Metodologi dan Teknik Penulisan Skripsi, Tesis \& Disertasi. Yogyakarta: Elmatera.

Karmawan, I. G. M. (2014). Pada Koperasi Tangerang. Com Tech, 5(27), 963-972.

Ningsih, N., Isnaini, F., Handayani, N., \& Neneng, N. (2017). Pengembangan Sistem Perhitungan Shu (Sisa Hasil Usaha) Untuk Meningkatkan Penghasilan Anggota Pada Koperasi Manunggal Karya. Jurnal Tekno Kompak, 11(1), 10. https://doi.org/10.33365/jtk.v11i1.168

Sihombing, D. O., Nugraha, W., \& Andani, F. (2016). Aplikasi Pengelolaan Data Order Mkios Berbasis Web Pada TDC PT. Telesindo Shop Pontianak. Simposium Nasional Ilmu Pengetahuan Dan Teknologi (SIMNASIPTEK) 2016 ISBN: 978-60261268-0-1, 129-138. 